\title{
The Effect of Planning on the Iranian EFL Learners` Performance of Grammatical Collocations in Speech
}

\author{
Dariush Nejadansari \\ English Department, Faculty of Foreign Languages, University of Isfahan \\ Isfahan 81746-7344, Iran \\ Tel: 98-311-793-2100_Ｅ-mail: nejadansari@gmail.com
}

Ehsan Alijanian (Corresponding author)

University of Isfahan

E-mail: ehsanalijanian@gmail.com

Received: April 30, 2012

Accepted: May 21, 2012

Published: June 15, 2012

doi:10.5430/wjel.v2n2p2

URL: http://dx.doi.org/10.5430/wjel.v2n2p2

\begin{abstract}
The present study explores the effects of pre-task as well as on-line planning on the production of grammatical collocations in speech. Also the impact of language of inner speech during planning was probed. Participants of the study were 45 advanced Iranian EFL learners in a private English institute. Data was elicited through using a narrative task. The results indicate that although on-line planning can significantly improve learners 'production of grammatical collocations in speech, effect of pre-task planning on learners` performance of grammatical collocations is not noticeable. Also thinking in Persian combined with English during planning had the most noticed effect on the accuracy rate of participants' speech. Giving sufficient time to learners during task performance and the prominence of metecognitive strategy training can be considered as the pedagogical implications of the study.
\end{abstract}

Keywords: On-line planning, Pre-task planning, Grammatical collocations, Inner speech

\section{Introduction}

One of the key components of language proficiency which makes a positive contribution to the way learners speak, listen, read, and write is sufficient knowledge of collocations. Thus, it is of great importance that L2 learners have a good command of the particular patterns in which words are frequently grouped. If collocational associations are not learned as part of the L2 knowledge, the learners` speech or writing will be judged as non-native or simply as odd.

Prior research on collocations has neglected two important issues; first, the majority of collocation research has emphasized written collocations (Farghal \& Obiedat, 1995; Liu, 1999; Mahmoud, 2005); only a few examined collocations in speech (Hsu \& Chiu, 2008). Research on oral collocation seems important. Correct collocation use in oral conversation is essential for clear and fluent speech. Collocational flaws in speech can easily cause communication failure. Similar to written collocational errors, oral collocational errors are also essential in EFL learners' speech (Tang, 2004). Speaking is different from writing in nature and oral collocations are usually more unplanned, more context-dependent, and less editable than written collocations. However, up to now, there has not been enough empirical research on collocations to investigate how and why collocational errors are created in speech.

Second, previous studies on collocations may have neglected to explore the role of cognitive factors and variables that cause learners' errors. Previous L2 research on learners' use of collocations traditionally emphasizes learners' collocational errors for diagnostic purposes. According to Benson et al. (1986), such errors are classified into a pre-constructed coding scheme as a way to categorize common collocation types and to explore problem sources of miscollocations. The insufficient number of studies in these two areas thus obliged the researchers to investigate the influences of cognitive factors on learners' production of oral collocations. 


\subsection{Planning Effect on the Production of Collocations}

Previously, some SLA researchers have examined the impact of planning on language production (Crookes, 1989, Ellis, 1987; Foster \& Skehan, 1996; Mehnert 1998; Ortega 1999; Wendel, 1997). These studies mostly take ideas from information processing theory, which claims that human beings possess a limited processing capacity and, as a result, are not able to attend fully to all aspects of a task (Anderson, 1995; Newell \& Simon, 1972). However, when learners have the opportunity to plan the linguistic and propositional content of an upcoming task, they can compensate for these processing limitations and, as a result, they can increase the quality of their linguistic output (Skehan, 1996).

Three aspects of linguistic performance have been distinguished: fluency, complexity, and accuracy (Skehan, 1996). Accuracy which is our concern here is the extent to which the language produced corresponds to target language norms. Prior research indicates that planning in advance has a positive effect on language production, especially where fluency and complexity are concerned (Ortega, 1999). In contrast, when it comes to accuracy there is no consensus on the impact of task planning. According to Yuan and Ellis (2003) a number of factors influence whether pre-task planning leads to increased accuracy: The kind of planning (unguided planning favors accuracy), the grammatical point involved (planning may enhance accuracy of features for which there is a clear rule), the difficulty of the task (an easy task predisposes attention to accuracy), the length of planning time allocated (learners channel attention to accuracy if given limited time), and the proficiency level of the learners (learners with higher proficiency seem better equipped to benefit from planning opportunities).

Ellis (1987) investigated the effect of on-line versus pre-task planning on the accuracy of L2 production. He found that the crucial factor influencing accuracy was the opportunity to plan on-line and not pre-task planning. Studies that investigated accuracy in narrative production suggest that whereas on-line planning resulted in greater accuracy of L2 learners` production, pre-task planning did not. (e. g., Ellis \& Yuan, 2004; Wendel, 1997; Yuan \& Ellis, 2003). These results suggest that L2 learners are only able to increase the accuracy of their oral production when they are focused on form and have sufficient time to formulate what they want to say and monitor their output (Ellis \& Yuan, 2004). In previous studies, accuracy was mostly measured by calculating the number of error free clauses in terms of syntax, morphology, and lexis (Ellis \& Yuan, 2004); but in no previous study, collocations were considered separately. Based on what has been discussed about planning so far, it seems that there can be a relationship between planning and production of collocations.

\subsection{Language of the Thought and Production of Collocations}

Field (2004) described an individual`s inner speech as the voice in the head. Inner speech as an internal cognitive activity is strongly associated with the mapping of different layers of language components in an L2, e.g., dealing with linguistic elements like sound, word, phrase, sentence, and structure (de Guerrero, 1994). Ushakova (1994) perceived it as 'mechanisms hidden from direct observation, comprising functional structures for word storage, relations between words, semantic fields, grammatical rules, and rules for discourse production' (p. 135).

One of the major aspects of inner speech is language for thinking. Speaking from a pedagogic point of view, a common belief about language for thinking is that thinking in the target language is beneficial to target language learning. The rationale behind this assumption is that learners who think more in the target language are more likely to be 'idiomatically accurate' in the target language (Cohen, 1995, p. 6). A key issue, however, is the extent to which the language used in inner speech is indicative of correct production of the language produced by the learners.

A study done by Lantolf (2000) suggests that advanced level learners made fuller use of their L2. Based on the results of a minisurvey, Cohen (1995) proposed that the benefits of thinking in the target language include increasing a learner's communicative and linguistic competence, decreasing hesitation while speaking, effectively practicing for real conversation, and aiding oral communication and reading comprehension; nevertheless, thinking in the target language that the student is still learning may also deteriorate or slow a learner's thinking process. Moreover, Cohen (1995) indicated that researchers need to investigate language of the thought to measure the effect of thinking in L1 or L2 on the performance in L2 tasks. However, since Cohen's work was published in 1995, it seems that there is little research on the effect of language of the thought on oral performance in EFL context. It is reasonable to think that choice of L1 or L2 for thinking can impact learner`s production of collocations.

\subsection{Notions of Collocations}

Lien (2003) believes that there are two theoretical traditions of collocations; lexis-oriented and grammar-oriented tradition. The former can highlight the meaning of the word as obtained from co-occurring counterparts and the latter thinks of collocations as lexically determined and grammatically restricted sequences of words (Kjellmer, 1984).

In the lexis-oriented tradition, the meaning of words is primarily determined by association of that word with 
neighboring words, so collocations are defined as habitually co-occurring word combinations (Halliday, 1966; Leech, 1974). Halliday (1966), for instance, referred to collocations as 'co- occurrence of two words, independent of grammatical types and likely to take place over sentence boundaries' (p. 148). This claim was also strongly advocated by Leech (1974) who stressed the meaning of words as associated with environment. The second tradition, the grammar-oriented view, puts emphasis on syntactic features of words. Mitchell (1971) contended that collocations should be studied on the basis of grammatical associations. The focus of attention in this study is lexis and grammar, and therefore it should be essential for researchers to investigate semantic and grammatical associations between words as well.

Three important categories of collocations that have received attention in the field are restricted and open collocations (Cowie, 1981), downward and upward collocations (Sinclair, 1991), and lexical and grammatical collocations (Benson et al., 1986). One of the most common classifications in previous empirical research is the category used by Benson et al. (e.g., Hsu, 2007). According to Benson et al. (1986), there is a distinction between lexical and grammatical collocations. Lexical collocations come in seven combinations of collocational structures like 'adjective + noun' (e.g., strong man) or 'noun + verb' (e.g., bombs explode).

In the taxonomy of Benson et al. (1986) a grammatical collocation is a phrase consisting of a dominant word (noun, adjective, verb) and a proposition or a grammatical structure such as an infinitive or a clause (e.g., afraid of). They contain eight structures. However, only the first seven categories are presented here as they provide the background of the present study on grammatical collocations in speech. In this study grammatical collocations were chosen since they are primarily determined by syntactic features of words and it seems that planning and language of inner speech can have a more tangible effect on them.

<Table 1 about here>

In view of the above, the three research questions of the study are as follows:

1- Does pre-task planning affect EFL learners`oral production of grammatical collocations?

2- Does on-line planning affect EFL learners`oral production of grammatical collocations?

3- Does EFL learners` language of the thought during planning affect their oral production of grammatical collocations?

\section{Methodology}

\subsection{Participants}

The participants of this study are advanced Iranian EFL learners studying English in a private English institute in Iran. 45 students between 18 to 25 years of age were chosen from advanced classes. Our participants were male and had studied English for at least four years prior to our study. We divided them into three groups and measured the effect of pre-task lanning, on-line planning, and language of inner speech during planning on their production of grammatical collocations.

\subsection{Instrument}

Our task required participants to narrate a story based on one of the episodes of the British series Mr. Bean. According to Skehan and Foster (1999),

'The British television series Mr. Bean is an ideal source of narrative tasks because the episodes (a) are short (8 minutes) (b) are almost entirely mimed thus avoiding the obvious problem of needing to access linguistic complexity and comprehension skills, and, (c) have a proven international appeal. The desired qualities for the episodes were that the story be (a) easy to follow, without a British cultural bias; and (b) amusing and engaging, so that telling the story would be something the participants would be likely to enjoy' (p. 103).

A restaurant episode of Mr. Bean was chosen. In this episode Mr. Bean goes to a restaurant, receives the menu, orders steak, is served and then spends some time desperately trying to hide the food (which he thinks is too disgusting to eat) in many places and around the table.

In order to understand in which language our participants thought, during pre-task and on-line planning each student was asked orally which language he used for thinking.

\subsection{Procedures}

Our data was collected in two days from our two classes. The episode was played for each participant separately, and then each participant was asked to narrate the story and was audio recorded. Students were divided in three groups based 
on three conditions in performing the task; 15 students for no planning condition, 15 for pre-task planning condition, and the remaining 15 for on-line planning condition. In the following, task conditions are explained in detail.

\subsubsection{No Planning}

In this condition, participants in the control group were asked to perform the task immediately after watching the episode and had to complete the task in a limited time ( 2 minutes), so that they had no time for planning the task in advance and were pressured to perform the task thus there were restricting opportunities for on-line planning as well.

\subsubsection{Pre-task Planning}

For the pre-task planning condition, participants in the first experimental group were given 3 minutes to plan their performance of the task after they watched the episode. The participants were asked to plan their narratives in terms of content, organization, and language. They were given a sheet of paper to write notes but were reminded not to write the whole story. These notes were taken away before they started the task. They were given limited time ( 2 minutes) to narrate the story.

\subsubsection{On-line Planning}

They were given unlimited time to enable them to formulate and monitor their speech plans as they performed the task but they had to start to narrate the story immediately. The Participants here had no time for pre-task planning but ample time for on-line planning.

\subsection{Data Analysis}

The researchers with the help of a graduate student transcribed all the audio taped data. Then all the grammatical collocations were identified. For rating these collocations, English dictionaries including the BBI Combinatory Dictionary of English: A Guide to Word Combinations (Benson et al., 1986) was used. The percentage of errors in collocations was calculated for three task conditions and then one way analysis of variance was used to see if the differences were significant. Also the percentage of inaccuracy of collocations was calculated for learners who used different languages for inner speech during planning and through one way ANOVA the differences were analyzed.

\section{Results}

\subsection{Kind of Planning and Production of Grammatical Collocations}

Our initial analyses indicated that our 45 participants produced a total number of 1248 grammatical collocations of which 133 were erroneous (inaccuracy rate of $10.65 \%$ ). In order to investigate the relationship between planning and oral production of grammatical collocations, we employed a one way ANOVA between inaccuracy rates of the three groups. As Table 2 shows, we found a significant difference between the three conditions. Furthermore, the Fish Least Significant Difference (LSD) posthoc test was used. This test shows that on-line planning is significantly different to both pre-task and no planning condition in terms of having effects on oral production of collocations. In other words, Students who had the opportunity to plan on-line outperformed both no planning and pre-task planning groups in terms of correct production of grammatical collocations. The pre-task planning group performed better than the no planning group but the difference was not significant.

$<$ Table 2 about here>

\subsection{Type of Language of the Thought and Production of Grammatical Collocations}

Table 3 indicates that 17 students thought in Persian combined with English; another 7 only thought in Persian; and 6 thought in English. Table 3 shows that students who thought in Persian combined with English during task planning had the lowest inaccuracy rate followed by those who thought in English and those who thought in Persian. Another one way ANOVA was employed to examine the differences in performance of students who were involved in pre-task as well as on-line planning to see if the language in which they thought had a significant effect on oral production of grammatical collocations they produced. As Table 3 indicates a significant difference was found between the groups. LSD posthoc shows that Persian combined with English group`s performance was significantly better than both the English and the Persian group. But no significant difference was found between Persian and English groups in terms of oral production of grammatical collocations.

<Table 3 about here> 


\section{Discussion}

\subsection{Kind of Planning and Production of Grammatical Collocations}

The results of the study indicate that Pre-task planning does not significantly contribute to accuracy in terms of production of collocations although the inaccuracy rate of no planning condition was higher than pre-task planning. This is in line with the findings of a number of previous studies on the effect of pre-task planning on accuracy (Crookes, 1989; Wendel, 1997). Skehan and Foster (1999) also have expressed that learners are inclined to use their pre-task planning time to pay attention to how to organize and encode the propositional content rather than to search their linguistic repertoire to enhance accuracy. Also it can be mentioned that in both no planning and pre-task planning conditions participants may have used their time to access their lexicons rather than to attend to grammatical accuracy.

On the other hand, in on-line planning condition respondents performed significantly better than those in the no planning and pre-task planning conditions in terms of oral production of grammatical collocations. Wendel (1997) argues that accuracy increases as a result of what learners do during performance. It is also in parallel with the results of Ellis` (1987) study. According to Skehan`s (1998) dual processing model, learners` rule-based system needs more time and attentional capacity to be accessed. It can be mentioned that enhanced performance of learners is due to the time the participants had to make use of their grammatical knowledge during on-line planning. Yuan and Ellis (2003) mention that when learners have the opportunity to plan on-line, they are better able to access their long term memory systems. Here it seems that this has assisted the learners 'formulation stage of speech processing. Therefore, when speech production is unpressured as in planned language use, learners are better able to search their long term memory for grammatical information which is here embodied as production of grammatical collocations.

\subsection{Type of Language of the Thought and Production of Grammatical Collocations}

Our third research question examined how learners` language for thinking during planning impacts their oral production of grammatical collocations. The results indicate that students using Persian mixed with English during planning did significantly better than the other groups. This is an interesting finding which is contrary to traditional beliefs that thinking in an L2 facilitates language learning even in the case of advanced language learners.

This indicates that metacognitive processes such as inner speech help learners in monitoring and planning of their language production. Purpura (1997) believes that 'metacognitive strategies involve planning for learning, thinking about the learning process as it is taking place, monitoring of one`s production or comprehension, and evaluating learning after an activity is completed' (as cited in Brown, 2000, p. 124). According to O'Malley, Chamot, and Kupper (1989), 'metacognitive skill is concerned with knowing about learning and controlling learning through planning, monitoring, and evaluating the learning activity' (p. 422).

On the other hand, if a learner makes abundant use of L1 then s/he will have to resort to translation in L2 production. Goh (2002) has made it clear that translation is a debilitating factor that hinders learners from accessing linguistic clues because of the pressure that it puts on the cognitive processing. Our finding is, therefore, in line with previous research. On the other hand, if L2 is used as the main thinking tool, learners` weak English competence might also deteriorate language production. But it should be mentioned that thinking in the L2 helps learners limit the transfer errors from L1 (Brown, 2001). With this in mind, we can make the claim that it is beneficial to use L2 in an appropriate degree in order to decrease grammatical collocational errors in speech.

\section{Conclusion}

The study investigated the effects of two cognitive factors on oral production of collocations. Both pre-task (insignificantly) and on-line planning (significantly) reduced the inaccuracy rate of grammatical collocations in speech and the students who used Persian mixed with English for thinking during planning did better with regard to oral production of grammatical collocations. In this study, advanced Iranian language learners studying English in a language institute in foreign language setting were examined. It remains to be investigated to what level these results can be generalizable in other settings. Nevertheless, the results of the study shed light on the impact of two important cognitive factors in speech production.

A pivotal issue is if learners have opportunity for planning. It has been suggested that planning (especially on-line planning) lets learners better access their L2 knowledge, particularly their explicit knowledge which leads into increased accuracy in terms of grammatical collocations. In terms of implications of the study it can be stated that there is benefit in giving learners time to plan tasks. Giving time to learners for planning may be harmful to situational authenticity (Bachman \& Palmer, 1996) of the task because there is usually limited time available for planning in real-world tasks. But as Widdowson (1984) argues the goal of language teaching should not be to teach language as communication but for communication. Thus as Yuan and Ellis (2003) mention teachers need to prepare learners to communicate by developing their general linguistic capacity for communication. 
The study also demonstrated that the use of inner speech supports oral language production. Inner speech as a metalinguistic strategy can monitor, guide, and rate oral production. Importance of metacognitive skill training can be another implication of this study. The significance of controlling and influencing metacognitive activities in EFL classroom setting can be highlighted. Learners can be more successful in oral production if they are trained to control their metacognitive skills.

\section{References}

Anderson, J. R. (1995). Learning and memory: An integrated approach. New York: Wiley.

Bachman, L., \& Palmer, A. (1996). Language testing in practice: Designing and developing useful language tests. Oxford: Oxford university press.

Benson, M., Benson, E., \& Ilson, R. (1986). The BBI combinatory dictionary of English: A guide to word combinations. Amsterdam: John Benjamins.

Brown, H. D. (2000). Principles of language learning and teaching. New York: Longman.

Brown, H. D. (2001). Teaching by principles: An interactive approach to language pedagogy. New York: Longman.

Cohen, A. D. (1995). In which languages do/should multilinguals think? Language, Culture and Curriculum, 8, 1-15. http://dx.doi.org/10.1080/07908319509525194

Cowie, A. (1981). The treatment of collocations and idioms in learner's dictionaries. Applied Linguistics, 2, $223-235$. http://dx.doi.org/10.1093/applin/2.3.223

Crookes, G. (1989). Planning and interlanguage variation. Studies in Second Language Acquisition, 11, $367-83$. http://dx.doi.org/10.1017/S0272263100008391

Ellis, R. (1987). Interlanguage variability in narrative discourse: style in the use of the past tense. Studies in Second Language Acquisition, 9, 12-20. http://dx.doi.org/10.1017/S0272263100006483

Ellis, R., \& Yuan, F. (2004). The effects of planning on fluency, complexity, and accuracy in second language narrative writing. Studies in Second Language Acquisition, 26, 59-84. http://dx.doi.org/10.1017/S0272263104261034

Farghal, M., \& Obiedat, H. (1995). Collocations: A neglected variable in EFL. IRAL, 33, 315-331. http://dx.doi.org/10.1515/iral.1995.33.4.315

Field, J. (2004). Psycholinguistics: The key concepts. New York: Routledge.

Foster, P., \& Skehan, P. (1996). The influence of planning on performance in task-based learning. Studies in Second Language Acquisition, 18, 299-324. http://dx.doi.org/10.1017/S0272263100015047

Goh, C. C. M. (2002). Exploring listening comprehension tactics and their interaction patterns. System, 30, $185-206$. http://dx.doi.org/10.1016/S0346-251X(02)00004-0

Halliday, M. A. K. (1966). Lexis as a linguistic level. In C. E. Bazell, J. C. Catford, M. A. K. Halliday, \& R. H. Robins (Eds.), In memory of F. R. Firth (pp. 148-162). London: Longman.

Hsu, J-Y. (2007). Lexical collocations and their relation to the online writing of Taiwanese college English majors and non-Englishmajors. Electronic Journal of Foreign Language Teaching, 4, 192-209.

Hsu, J-Y., \& Chiu, C.-Y. (2008). Lexical collocations and their relation to speaking proficiency of college EFL learners in Taiwan. Asian EFL Journal, 10. Retrieved July 19, 2010, from the worldwide web: http://www.asian-efl-journal.com/March 08_jth.php.

Kjellmer, G. (1984). Some thoughts on collocational distinctiveness. In J. Aarts, \& W. Meijs (Eds.), Corpus linguistics: Recent development in the use of computer corpora in English language research (pp. 163-171). Amsterdam and Atlanta: Rodopi.

Lantolf J (2000). Second language learning as a mediated process. Language Teaching, 33, 79-69. http://dx.doi.org/10.1017/S0261444800015329

Leech, G. (1974). Semantics. Baltimore: Penguin Books.

Lien, H. Y. (2003). The effects of collocation instruction on the reading comprehension of Taiwanese college students. Unpublished doctoral dissertation, Indiana University of Pennsylvania. 
Liu, C. P. (1999). An analysis of collocational errors in EFL writing. In J. E. Katchen, \& Y. N. Leung (Eds.), The proceedings of the 8th English international symposium on English teaching (pp. 483-494). Taipei, R.O.C.: Crane Publishing.

Mahmoud, A. (2005). Collocation errors made by Arab learners of English. Asia EFL Journal. Retrieved July 19, 2010, from the worldwide web: http://www.asian-efl-journal.com/pta_August_05_ma.php.

Mehnert, U. (1998). The effects of different lengths of time for planning on second language performance. Studies in Second Language Acquisition, 20, 52-83. http://dx.doi.org/10.1017/S0272263198001041

Mitchell, T. F. (1971). Linguistics 'goings-on': Collocations and other lexical matters on the syntagmatic record. Archivum Linguisticum, 2, 35-69.

Newwell, A. \& Simon, H. (1972). Human problem solving. Englewood cliffs, NJ: prentice hall.

O’Malley, J. M., Chamot, A. U., \& Kupper, L. (1989). Listening comprehension strategies in second language acquisition. Applied Linguistics, 10, 418-437.

Ortega, L. (1999). Planning and focus on form in L2 oral performance. Studies in Second Language Acquisition, 21, 108-48. http://dx.doi.org/10.1017/S0272263199001047

Purpura, J. E. (1997). An analysis of the relationships between test takers' cognitive and metacognitive strategy use and second language test performance. Language Learning, 47, 289-325. http://dx.doi.org/10.1111/0023-8333.91997009

Sinclair, J. (1991). Corpus, concordance, collocation. Oxford: Oxford University Press.

Skehan, P. (1996). Second language acquisition research and task based instruction. In J. Willis, \& D. Willis (Eds.), Challenge and change in language teaching (pp.17-30). Oxford: Heinemann.

Skehan, P. (1998). A cognitive approach to language learning. Oxford: Oxford University Press.

Skehan, P., \& Foster, P. (1999). The influence of task structure and processing conditions on narrative retellings. Language Learning, 49, 93-120. http://dx.doi.org/10.1111/1467-9922.00071

Tang, Y. T. (2004). A study of the collocation errors in the oral and written production of the college students in Taiwan. Unpublished master' thesis, National Taiwan Normal University.

Ushakova, T. N. (1994). Inner speech and second language acquisition: An experimental- theoretical approach. In J. P. Lantolf, \& G. Appel (Eds.), Vygotskian approaches to second language research (pp. 135-156). Norwood, NJ: Ablex.

Wendel, J. N. (1997). Planning and second language narrative production. Unpublished doctoral dissertation, Temple University, Japan.

Widdowson, H. (1984). Explorations in applied linguistics Vol 2. Oxford: Oxford University Press.

Yuan, F., \& Ellis, R. (2003). The effects of pre-task planning and on-line planning on fluency, complexity, and accuracy in L2 monologic oral production. Applied Linguistics, 24, 1-27. http://dx.doi.org/10.1093/applin/24.1.1 
Table 1. Grammatical Collocation Categorization Designed by Benson et al. (1986)

\begin{tabular}{|l|l|l|}
\hline Type & \multicolumn{1}{|c|}{ Pattern } & \multicolumn{1}{c|}{ Examples } \\
\hline G1 & Noun + proposition & Blockade against, Apathy towards \\
\hline G2 & Noun + to + infinitive & $\begin{array}{l}\text { It was a pleasure to do it. } \\
\text { He felt a compulsion to do it. }\end{array}$ \\
\hline G3 & Noun + that clause & We reached an agreement that she represents us in the court. \\
\hline G4 & Proposition + noun combination & $\begin{array}{l}\text { To somebody`s advantage } \\
\text { On somebody`s advice }\end{array}$ \\
\hline G5 & Adjective + preposition combinations & Angry at everyone; Fond of children \\
\hline G6 & Predicate adjective + (to + infinitive) & $\begin{array}{l}\text { It was necessary to work. } \\
\text { The machine was designed to operate at high attitudes. }\end{array}$ \\
\hline G7 & Adjective + that clause & It is necessary that he be replaced immediately. \\
\hline
\end{tabular}

Table 2. Differences among Three Task Conditions in Inaccuracy Rates

\begin{tabular}{|l|c|c|c|c|c|c|}
\hline Conditions & $\begin{array}{c}\text { \# of } \\
\text { Participants }\end{array}$ & $\begin{array}{c}\text { \# of } \\
\text { Collocations }\end{array}$ & $\begin{array}{c}\text { \# of } \\
\text { Errors }\end{array}$ & $\begin{array}{c}\text { \% of } \\
\text { Errors }\end{array}$ & $\begin{array}{c}\text { SD } \\
\%\end{array}$ & $\begin{array}{c}\text { F } \\
\text { Comment }\end{array}$ \\
\hline No planning (NP) & 15 & 296 & 33 & 11.38 & .43 & $\begin{array}{c}.000^{*} \\
\text { NP<OP* } \\
\text { PP<OP* }\end{array}$ \\
\hline Pre-task planning (PP) & 15 & 358 & 40 & 11.14 & .45 & \\
\hline On-line planning (OP) & 15 & 594 & 60 & 10.09 & .35 & \\
\hline
\end{tabular}

$* \mathrm{p}<.05$

Table 3. Type of Language for Thinking and Inaccuracy Rated of Grammatical Collocations

\begin{tabular}{|l|c|c|c|c|c|}
\hline Group & N & M \% & SD \% & F & Comments \\
\hline $\begin{array}{l}\text { Persian mixed with English } \\
\text { (PE) }\end{array}$ & 17 & 9.99 & .58 & $.000^{*}$ & PE<P* \\
\hline $\begin{array}{l}\text { Persian } \\
\text { (P) }\end{array}$ & 7 & 10.82 & .26 & & PE $<\mathrm{E}^{*}$ \\
\hline $\begin{array}{l}\text { English } \\
(\mathbf{E})\end{array}$ & 6 & 11.05 & .37 & & \\
\hline$* \mathrm{p}<.05$ & & &
\end{tabular}

